\title{
Ascites in a Bully Female Pup - A Case Report
}

\author{
Neelam*, Jai Bhagwan and V.K. Jain \\ Department of Veterinary Medicine, \\ LLR University of Veterinary and Animal Sciences, Hisar - 125004, Haryana, India
}

*Corresponding author

\section{A B S T R A C T}

\section{Keywords \\ Ascites, Hepatic, Inappetance, \\ Haemato- \\ biochemical \\ Article Info \\ Accepted: \\ 20 January 2019 \\ Available Online: \\ 10 February 2019}

\section{Introduction}

Accumulation of serous fluid in the sac of peritoneal cavity is referred as ascites. It is one of the most common clinical problems found in dogs.

It may occur due to number of etiological factors viz. chronic hepatic failure, congestive heart failure, nephritic syndrome, malnutrition, hypoproteinemia, protein losing enteropathy, ankylostomiasis, abdominal neoplasia of different origin and protein loosing enteropathy (Randhawa et al., 1988: Pradhan et al., 2008 and Sujata et al., 2009). Since, ascites is also a clinical sign of some underline disease conditions, detailed investigations should be carried out to identify the actual cause of the disease.

\section{Case history and Clinical observations}

A four month old bully mongrel female pup was brought to TVCC, LUVAS, Hisar, with the history of progressive abdominal distension, inappetence, lethargy and weakness since one week. Clinical examination revealed pyrexia $\left(103.2^{0} \mathrm{~F}\right)$, distended abdomen on both sides with palpable fluid thrill, dyspnoea, dehydration and pale mucous membranes. Radiographic examination revealed the ground glass 
appearance in abdominal and thoracic cavity with slight pneumonic changes in lungs. Haematological findings revealed 7.7 gm per cent $(\%)$ of Haemoglobin, TLC (Total leukocytes count) $13410 / \mathrm{cmm}$ and DLC (Differential leukocytes count) - Neutrophils $86 \%$, Lymphocytes $12 \%$, eosinophils $1 \%$ and monocytes $1 \%$. The biochemical analysis of serum revealed higher levels of serum glutamic-pyruvate transaminase (SGPT) and serum glutamic-oxaloacetic transaminase (SGOT) $251 \quad \mathrm{IU} / \mathrm{L}$ and $113.2 \mathrm{IU} / \mathrm{L}$ respectively, and decreased level of total protein $4.5 \mathrm{~g} / \mathrm{dl}$. Blood urea nitrogen and serum creatinine levels were $22.49 \mathrm{mg} \%, 0.52$ mg\% respectively.

\section{Treatment and Discussion}

The dog was treated with Inj. DNS $100 \mathrm{ml}$ IV; Inj. amoxicillin and sulbactam @ 10 mg/kg I/M; Inj. furosemide @ 2 mg/kg I/M; Inj. analgin @ $0.5 \mathrm{ml}$ and Inj. Tribivet $0.5 \mathrm{ml}$ I/M daily for a week along with supportive therapy with syrup livotas pet half tsf. b.i.d for 20 days. The owner was advised to feed chicken soup daily for 20 days along with restricted dietary sodium intake. Subsequently, reduction in abdominal distension was observed from $4^{\text {th }}$ day of treatment and the animal became completely healthy by $20^{\text {th }}$ day. The recorded clinical symptoms simulated with Wadhwa et al., (1995) and Dabas et al., (2011). Haematological examination, revealed slight decrease in $\mathrm{Hb}$ concentration and leukocytosis with neutrophilia (Rakesh and Shanti, 1994 and Kumar, 2002). Higher SGPT and SGOT values were due to hepatic insufficiency with hepatic damage resulting into leakage of enzyme from hepatocytes into blood stream (Cornelius et al., 1975). The level of total proteins indicated hypoproteinaemia (Skardova, 1991). Serum blood urea nitrogen and creatinine values indicated normal renal function. The detailed biochemical analysis confirmed that ascites was of hepatic origin and the same results were observed by Kumar et al., (2016).

Since, the animal was suffering with chronic illness and the clinico-pathological parameters were also suggestive of infection, the line of treatment was chosen with administration of higher antibiotic dose to minimize bacterial infection via the portal circulation, along with supportive therapy and the pup responded well to the treatment.

\section{References}

Cornelius, L.M., Thrall, D.E., Halliwell, W.H., Frank, G.M., Kern, A.J. and Woods, C.B. 1975. Anomalous portosystemic anastomoses associated with chronic hepatic insufficiency in six young dogs. Journal of the American Veterinary Medical Association. 167(3): 220-228.

Dabas, V.S., Suthar, D.N., Chaudhari, C.F., Modi, L.C. and Vihol, P.D. 2011. Ascites of Spleenic Origin in a Mongrel Female Dog-A Case Report. Veterinary World. 4(8): 376.

Kumar, A., Das, S. and Mohanty, D.N. 2016. Therapeutic management of ascites in GSD female dog. International Journal of Science, Environment and Technology. 5(2): 654-657.

Kumar, S. 2002.Thesis Abstract. Journal of Canine Development and Research. 2:78.

Pradhan, M.S., Dakshinkar, N.P., Waghaye, U.G. and Bodkhe, A.M. 2008. Successful treatment of Ascites of hepatic origin in Dog. Veterinary world. 1(1): 23.

Rakesh and Shanti. 1994. Ascites in a bitch. Indian Journal of Veterinary Medicine. 18: 56-57.

Randhawa, S.S., Dhaliwal, P.S., Dua, S. and Singh, K.B. 1988. Ascites of hepatic 
origin in dogs. Indian Journal of Animal Health. 12: 165-166.

Škardová, I., 1991. Occurrence of ascites abdominalis in dogs. The Journal of nutrition. 121: 159-160.

Sujata, T., Randhawa, C.S., and Uppal, S.K. 2009. Ascites associated with ancylostomiasis in a pup: A case report. Intas Polivet. 10(2): 357-359.

Wadhwa, D.R., Rao, V.N., Prasad, B. and Mandial, R.K. 1995. Ascites in dogs and its management. Indian Veterinary Journal. 72(12): 1297-1299.

\section{How to cite this article:}

Neelam, Jai Bhagwan and Jain, V.K. 2019. Ascites in a Bully Female Pup - A Case Report. Int.J.Curr.Microbiol.App.Sci. 8(02): 2949-2951. doi: https://doi.org/10.20546/ijcmas.2019.802.343 